\title{
FLUTES ON BARE BEDROCK
}

\author{
By WiBJöRn KarLÉN \\ (Naturgeografiska Institutionen, Stockholms Universitet, Drottninggatan 120, I I 386 Stockholm, \\ Sweden)
}

\begin{abstract}
Flutes, up to about $500 \mathrm{~m}$ long, were observed on bare glacially polished bedrock at the margin of the glacier Svartisen in northern Norway. Since these ridges were lying directly on bedrock that had no till cover, they can hardly have been formed by post-depositional deformation of pre-existing materials, a mechanism for formation favoured by Boulton.

RÉsumé. Flutes sur un lit rocheux nu. Des flutes allant jusqu'à $500 \mathrm{~m}$ de long ont été observées sur un lit rocheux nu poli par un glacier dans la zone marginale du glacier Svartisen dans la Norvège septentionale. Comme ces cannelures ont été placées directement sur la roche du lit, qui n'a pas de couverture mosaique, elles peuvent difficilement avoir été formées par une déformation après dépôt de matériaux pré-existants, le mécanisme avancé par Boulton pour expliquer leur formation.

Zusammenfassung. "Flutes" auf nacktem Fels. Flutes bis zu $500 \mathrm{~m}$ Länge wurden auf nacktem, poliertem Fels am Rande des Svartisen-Gletschers in Nord-Norwegen beobachtet. Da diese Rücken unmittelbar auf Felsuntergrund, der keinen Schuttmantel trug, gelegen wurden, können sie kaum durch nachträgliche Deformation von vorhandenem Ablagerungsmaterial entstanden sein, - ein Mechanismus, der von Boulton vorgeschlagen wird.
\end{abstract}

\section{INTRODUCTION}

The formation of flutes has been discussed thoroughly by Boulton (1976). He concluded that this feature frequently, but not exclusively, is a result of "post-depositional deformation of pre-existing materials" (p. 309). Observations from northern Scandinavia suggest that this is not the only method by which flutes are formed. Therefore, the author believes it might be too early to introduce a genetic definition of the term "flute".

\section{ObSERVATIONS FROM SVARTISEN}

Two ice caps in northern Norway are collectively called Svartisen. These glaciers have retreated a considerable distance during the twentieth century. Large areas of glacially polished and striated bedrock with no or only a patchy cover of till have become exposed. About $8 \mathrm{~km}$ east-north-east of Snøtiden, the highest peak in the area, large bedrock areas are striped with long, sparsely spaced ridges of drift (Figs I and 2). These ridges are parallel and have the same orientation as the striations on the bedrock between them. Several ridges begin at bedrock obstacles. These obstacles apparently serve the same function in the formation of the ridges as the large boulders heading flutes described elsewhere (Dyson, 1952, p. 204; Hoppe and Schytt, 1953, p. 109, I 14; Schytt, 1959, p. 223; Boulton, 1976, p. 289). Many ridges can be traced from a zone semi-parallel to the present ice margin and located at a short distance from this. Some ridges can be followed about $500 \mathrm{~m}$ across the exposed bedrock. They can also be seen passing across a previously over-ridden end moraine. These ridges are approximately $\mathrm{I} \mathrm{m}$ wide. When consisting of only fine material, they are seldom more than $5 \mathrm{~cm}$ high, although they are thicker when rocks and boulders are included. In places where they cross the end moraine they are higher. A grain-size analysis shows that these ridges consist of till. The features observed at Svartisen have all the characteristics of flutes as the term is commonly used (Dyson, 1952; Hoppe and Schytt, 1953; Schytt, 1959; Boulton, 1976). Although the flutes described above cover an unusually large bedrock area $(500 \mathrm{~m}$ by $500 \mathrm{~m})$, several similar localities where flutes occur on small rock outcrops have been observed in front of other glaciers in northern Scandinavia. This indicates that the occurrence of flutes on bare bedrock is not unique and may in fact be common in northern Scandinavia.

\section{FORMATION OF FLUTES ON BEDROCK}

The observations at the locality described above do not reveal how flutes are formed but the fact that they are located directly on bedrock excludes "post-depositional deformation of pre-existing materials". If the ridges are not formed by deformation of the pre-existing material, it remains to explain how the flutes have formed and how they have been brought to the place where they are now. 


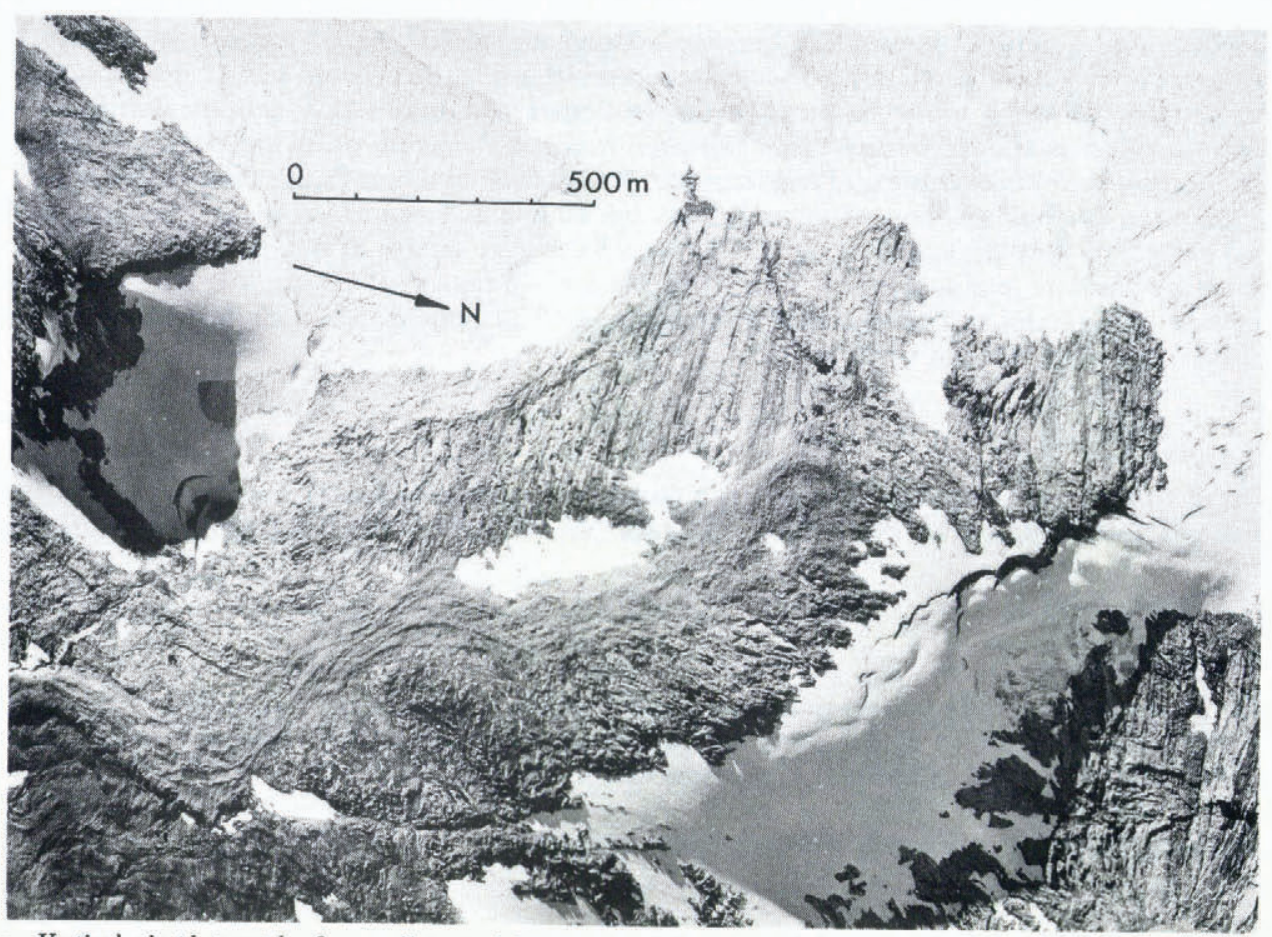

Fig. I. Vertical air photograph of a small part of the margin of Svartisen. A large number of flutes are located on glacially polished bedrock. Some flutes can be seen on the moraine. (Photograph by Fjellanger-Wideree, 3205 o8.)

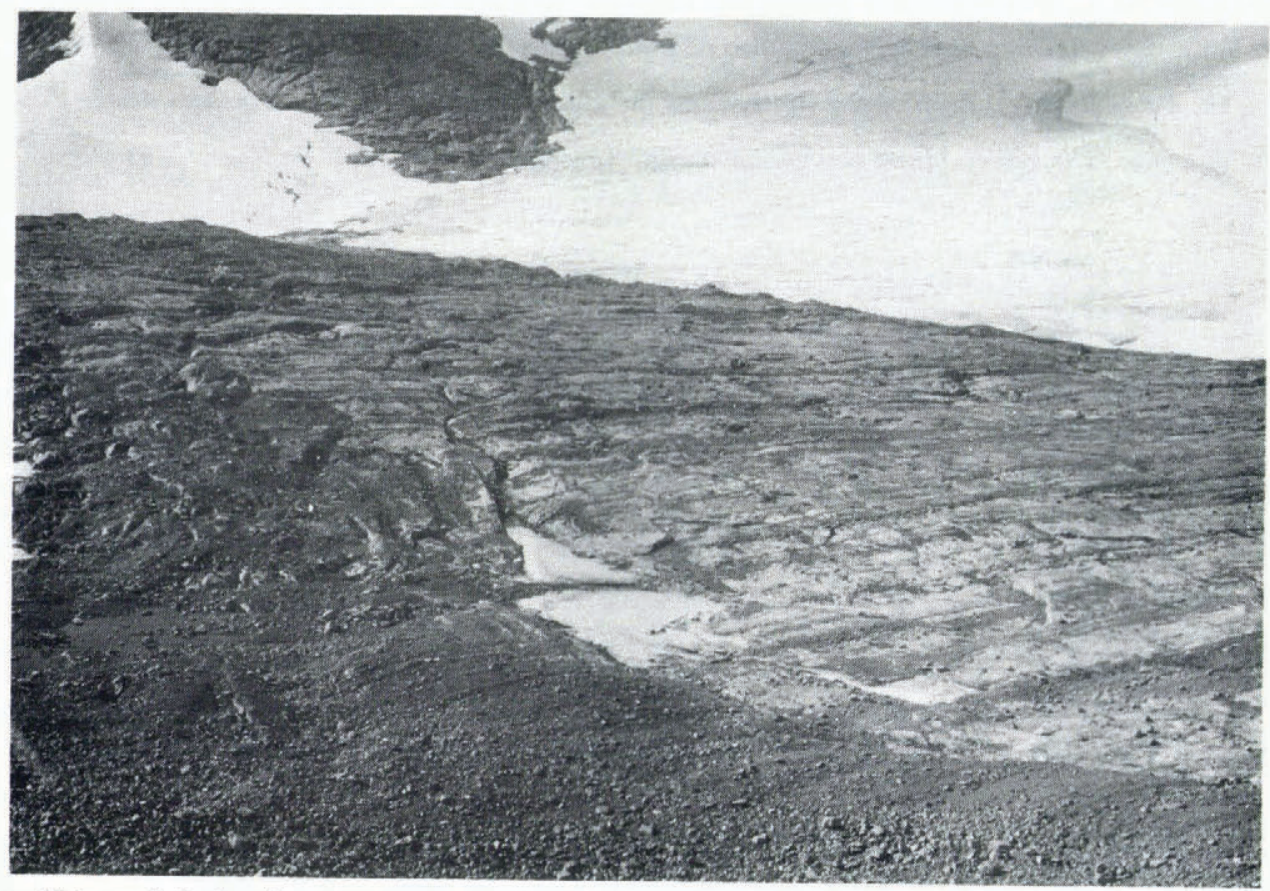

Fig. 2. Flutes on bedrock and on an over-run moraine. The flutes are relatively low and flat on the bedrock, while they are of ordinary dimensions on the moraine. (Photograph by W. Karlén, 25 August 1977.) 
An observation in front of another outlet glacier of Svartisen, Østerdalsisen, might have some bearing on this problem. In a natural cave formed between bedrock and glacial ice, several narrow parallel bands of till were observed in the roof. The bands were very thin and they could not be traced outside the glacier margin. However, if the bands of till had included more material, it is likely that flutes would have been formed on the bedrock surface. The observation of the bands of till indicates that strips of till can be incorporated in the bottom of a glacier and brought forward in a frozen state to the glacier sole. In a discussion of the formation of flutes, Schytt (in Hoppe and Schytt, 1952, p. 114; Schytt, 1959, p. 223) suggested that till is pressed up into hollows formed in the lee of boulders, where the till then freezes to the basal ice, and so is carried along with the ice. This method of transport is supported by the observation of the strips of till in the roof of the ice cave. The method by which the till is concentrated into bands, however, remains unclear.

\section{Conclusion}

The fact that well-developed flutes occur on large areas of exposed bedrock suggests that the genetic definition of flutes proposed by Boulton is not suitable and the term "flute" should retain its descriptive sense.

\section{AcKNoWLEDGements}

The observations noted in this paper were made in connection with field work on glacial variations in the Svartisen area, funded by National Science Foundation Grant EAR 7702645. Professor Valter Schytt has read and made valuable comments on the manuscript.

MS. received 5 November 1979 and in revised form 8 January 1980

\section{REFERENCES}

Boulton, G. S. 1976. The origin of glacially fluted surfaces-observations and theory. Fournal of Glaciology, Vol. 1 7, No. 76 , p. 287-309.

Dyson, J. L. I 1952 . Ice-ridged moraines and their relation to glaciers. American fournal of Science, Vol. 250, No. 3 , p. 204-II.

Hoppe, G., and Schytt, V. 1953. Some observations on fluted moraine surfaces. Geografiska Annaler, Vol. 35, No. 2, p. 105-15.

Schytt, V. 1959. The glaciers of the Kebnekajse-massif. Geografiska Annaler, Vol. 41, No. 4, p. 213-27. 